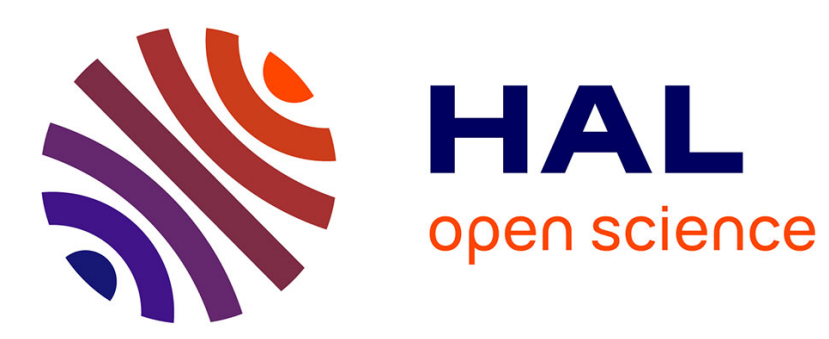

\title{
Talking about counterfactual worlds: A comparative study of French and Spanish
}

\author{
Isabel Repiso
}

\section{To cite this version:}

Isabel Repiso. Talking about counterfactual worlds: A comparative study of French and Spanish. Journal of Romance Studies, 2015, 15 (1), pp.52-72. 10.3828/jrs.15.1.52 . halshs-03330878v2

\section{HAL Id: halshs-03330878 \\ https://shs.hal.science/halshs-03330878v2}

Submitted on 6 Sep 2021

HAL is a multi-disciplinary open access archive for the deposit and dissemination of scientific research documents, whether they are published or not. The documents may come from teaching and research institutions in France or abroad, or from public or private research centers.
L'archive ouverte pluridisciplinaire HAL, est destinée au dépôt et à la diffusion de documents scientifiques de niveau recherche, publiés ou non, émanant des établissements d'enseignement et de recherche français ou étrangers, des laboratoires publics ou privés. 
Talking about counterfactual worlds

2 A comparative study of French and Spanish

3 Isabel Repiso

4 University of Upper Alsace

5

\section{Abstract}

Counterfactual thinking is a cognitive process in which reality is compared to an imagined view of what might have been. Previous studies in Linguistics have focused on the description of the conditional construction if $P$ (then) $Q$. Our study aims to compare the grammatical devices used by thirty French native speakers and thirty Spanish native speakers. Participants were presented with a story that led to a particular outcome and were asked to provide alternative scenarios that might have prevented such an outcome from happening. The results showed (i) that counterfactuality is not expressed most frequently by conditional constructions and (ii) that the use of evaluative modal markers within the mutation core is a salient difference between French and Spanish. The minor role of conditional constructions suggests that the boundaries of conditionality as a conceptualization process need to be reconsidered within the realm of irreality. In addition, the frequency of evaluative modals in French suggests a preference for counterfactual scenarios that integrate an overt critical judgement from the speaker.

Keywords: conditionality, counterfactuality, modal verbs

\section{Introduction}

Counterfactual thinking is the cognitive process in which reality is compared to an imagined view of what might have been (Kahneman and Tversky 1982). Previous studies dealing with the description of counterfactuality have focused on the analysis of conditional sentences (Bates 1976; Bloom 1981; Reilly 1982; Au 1983; Bernini 1994; Chini 1995; Harris et al. 1996; Katis 1997; Schouten 2000; Yeh and Gentner 2005; Grevisse 1986; Renzi and Salvi 1991; Campos 1993; Alarcos-Llorach 1999). However, evidence of the marking of counterfactuality in ways other than using conditional sentences has been found in simple clauses in natural languages (Hellberg 1971; Van Linden and Verstraete 2008). This article provides original insights into the expression of counterfactuality in French and Spanish. Eventual differences in the grammatical devices preferred in French and Spanish might underlie different semantic patterns in the conceptualization of counterfactual states of affairs. The ultimate objective of the present study is to analyse whether the grammatical categories by which the native speakers talk about irreality are salient in the same way in French and Spanish. This article is organized in seven sections. In the next Section, we provide a formal description of conditional constructions and we present the conceptual foundations of counterfactuality. In Section 3, we offer a typological description of counterfactual conditional clauses in French and Spanish. Subsequently, we introduce the materials and instructions used to elicit counterfactual responses. Statistical results are presented in Section 5. The main findings are discussed and related to previous studies, and the conclusions summarized in the final sections. 


\section{State of the art}

The notion of counterfactuality has typically been linked to a particular linguistic construction, the conditional construction If $P$ (then) $Q$ :

(1) If kangaroos had no tails, they would topple over.

This kind of construction generally consists of two clauses, called the protasis and apodosis, respectively. The protasis is a subordinate clause introduced by a conjunction (if) and characterized by a particular tense form: in the English example (1), a form that looks like a simple past, but is considered to be a past subjunctive. The apodosis is a main clause typically characterized by a particular verb form, again in (1), the combination of would + infinitive (the present conditional). In fact, it is this construction in English, and its counterparts in other languages, that are generally described in traditional grammar books as pertaining to counterfactuality (Section 3 ) and most of the work on the description of counterfactuality deals with this type of construction (Sections 2.2 and 2.3). However, this is not the only way in which speakers can talk about worlds that are explicitly contrasted to what is really the case. In this study, our goal is to see how speakers proceed when they are attempting to speak about counterfactual worlds in French and Spanish. Do they employ conditional constructions, or do they use different strategies?

\subsection{Conceptual foundations}

It is not our aim to present a complete theoretical picture of the contributions of philosophy, psychology and linguistics to counterfactuality but rather to introduce three frameworks from which counterfactuality has been studied. We consider counterfactual thinking to be a cognitive process in which reality is compared to an imagined view of what might have been (Kahneman and Tversky 1982). This process is based on the mental construction of alternatives to factual states of affairs (Wells and Gavanski 1989). Counterfactuality has been described as a semantic domain related to three main topics:

- causality, because of the causal relation that may hold between the main clause (Q) and the subordinate clause (P) within conditional constructions (Hume 1739; Lewis 1973; Mackie 1980);

- epistemic modality, because of the speaker's degree of uncertainty involving the content of their statement (Lyons 1977; Palmer 1986; Fauconnier 1984; Dancygier and Sweetser 1996);

- irreality, because of the definition of counterfactuality as one semantic subdomain within irreality, alongside the non-exclusion-of-factuality and non-referentiality (Pietrandrea 2012).

Along a semantic scale, counterfactual conditionals express a low degree of probability and a high degree of hypotheticality (Comrie 1986). In counterfactual conditional constructions, the relationship between $\mathrm{P}$ and $\mathrm{Q}$ holds in the past. This is because counterfactuality is deeply related to the speaker's state-of-knowledge and in particular to their certainty about the non-actualization of a given process. The past is a better known domain compared to the present and the future and thus counterfactuality represents a well delimited frame from which people can conceive other possible worlds $\left(W_{1}, W_{2}, W_{3}\right)$ 
which differ from the world as it is $\left(\mathrm{W}_{0}\right)$. This means that any antecedent $(\mathrm{P})$ introduced by the speaker is false at the time when something is said (the time of utterance). Consider the example below:

75 (2) If Karen hadn't eaten seafood, she would still be alive.

This is regularly understood to mean that the speaker asserts that Karen had in fact eaten seafood, i.e. the sentence Karen has not eaten seafood is false. The certainty of the speaker about the nonactualization of the process is a major feature that differentiates counterfactuality from potentiality (Verstraete 2005). Beyond conditional constructions, the combination of a past tense and a modal particle has been described as a frequent marker of counterfactuality (Van Linden and Verstraete 2008). For example:

(3) The police should have done something to prevent the killing.

These authors posit that counterfactual statements are semantically double- layered, since they combine potentiality, i.e. the speaker presents a given state of affairs as possible, desirable, imminent or intended, and pastness, i.e. the speaker is aware of the non-actualization of what is being said. In English, the interpretation of a counterfactual statement comes from the compositional semantics of the modal element should, which frames it in a virtual locus, and the past marker have done, which marks a non-actualized state of affairs.

\subsection{Rationale}

A detailed reading of the literature on counterfactuality leads us to affirm that (i) in general this concept has failed to be analysed beyond conditional constructions and that (ii) a terminological problem remains in respect to its meaning. A major contribution to the linguistic properties of counterfactuality was made by the publication of the collective volumes On Conditionals and On Conditionals Again (Ferguson et al. 1986; Athanasiadou and Dirven 1997), in which conditionality was introduced as a semantic category covering both hypotheticality and counterfactuality. These volumes, together with earlier studies (Bates 1976; Bloom 1981; Reilly 1982; Au 1983; Liu 1985) and later studies (Bernini 1994; Chini 1995; Schouten 2000; Yeh and Gentner 2005), contributed to placing counterfactuality under the umbrella of conditional constructions. To date, terminological incoherence subsists across grammatical traditions and some authors claim that counterfactuality strictly covers the semantic domain of irreality (Renzi and Salvi 1991; Riegel et al. 1994; Real Academia Española 2009), whereas other authors consider it as a broader notion covering both irrealis and imagined conditions (Grevisse and Goosse 2008). Within the realm of irreality, it is generally assumed that conditional constructions can express values related to a past irrealis or a present irrealis (Harris 1986; Riegel et al. 2001; Grevisse and Goosse 2008).1 We adhere to the theoretical framework that places counterfactuality in the semantic subdomain of irreality, alongside subdomains of non-exclusion-of-factuality and non-referentiality (Pietrandrea 2012). We consider counterfactuality to be a well delimited field that, unlike potentiality, implies the certainty of the speaker about the non-actualization of the process (Verstraete 2005).

\section{Cross-linguistic description of counterfactual conditionals}


The typological distance between French and Spanish in counterfactual conditionals resides in the protasis: French requires the indicative mood whereas Spanish requires the subjunctive mood. Concerning the apodosis or main clause, the two languages converge in the canonical use of the perfect conditional.

\subsection{Counterfactual conditionals in French}

In spoken French the canonical mood in the protasis is the pluperfect indicative (cf. Table 1).2 This means that the indicative mood in French is associated with two different readings: factual and hypothetical, although the presence of the morpheme si (if) usually disambiguates this dichotomy. More problematic is the disambiguation of the pluperfect indicative in the protasis, which can encode either potential or irrealis semantic values. In this case, it is generally assumed that the disambiguation depends on the context (Riegel et al. 1994; Vetters 1994; Patard 2007; LeBlanc 2009).3 Double conditional marking in both the protasis and the apodosis (4) is considered a violation of the French standard. For example:

(4) Si vous m'auriez ennuyé, je vous l'aurais dit. (Grevisse 1986: 1686)

If you 'would have annoyed' me, I would have told you.

Example (4) is generally attributed to familiar uses (Grevisse 1986) and to verbal symmetry between the protasis and the apodosis in some hypothetical and concessive constructions (Riegel et al. 1994).4 Nevertheless, when the protasis is introduced by the constructions au cas où or dans le cas où (in case) the use of verbal forms of the conditional or the subjunctive is considered canonical, instead (Grevisse 1986). Among the less frequently described grammatical markers in French, we find the modal verbs pouvoir and devoir appearing in the past participle verbal forms of the perfect conditional:

(5) Jean aurait pu être quelqu'un d'autre. (Fauconnier 1984: 144)

Jean could have been someone else.

Table 1. Counterfactual canonical conditionals in French and Spanish

\begin{tabular}{|l|l|l|l|}
\cline { 2 - 3 } \multicolumn{1}{c|}{} & If $P$ & (then) $Q$ & Example \\
\hline FR & $\begin{array}{l}\text { Indica- } \\
\text { tive }\end{array}$ & $\begin{array}{l}\text { Condi- } \\
\text { tional }\end{array}$ & $\begin{array}{l}\text { Si tu avais admis cette opinion, tu aurais eu tort (Grevisse 1986) } \\
\text { If you had agreed with that opinion you would have been wrong }\end{array}$ \\
\cline { 1 - 1 } & $\begin{array}{l}\text { Subjunc } \\
\text {-tive }\end{array}$ & $\begin{array}{l}\text { Si te hubieses quedado, habrías visto algo bueno (Alarcos- } \\
\text { Llorach 1999) } \\
\text { If you had remained you would have seen something good }\end{array}$ \\
\hline
\end{tabular}

\subsection{Counterfactual conditionals in Spanish}


Disambiguation between factual and counterfactual conditionals in Spanish is achieved by using the indicative mood or the subjunctive mood in the protasis (Alarcos-Llorach 1999). The main clause or apodosis is generally in the conditional, whereas the perfect subjunctive in the protasis (6) frames the content of the proposition in the past.

(6) Si te hubieses quedado, habrías visto algo bueno. (Alarcos-Llorach 1999: 474) If you had stayed, you would have seen something good.

In practice, a wide range of verbal combinations are observed in Spanish counterfactual conditionals, including symmetrical verb forms in the conditional tense in both the protasis and the apodosis (8) or in the subjunctive mood (7). For example:

(7) Si hubiera tenido dinero, hubiera ido a España. (Campos 1993: 163)

If I had money, I would have gone to Spain.

(8) Si habría tenido dinero, habría ido a España. (Campos 1993: 163)

If I had money, I would have gone to Spain.

The use of (7) has been described as a frequent structure in the Mexican variety of Spanish (Wald 1993) while the use of (8) has been observed in general in some dialectal varieties of Spanish (Alarcos-Llorach 1999) and in particular in Buenos Aires (Lavandera 1976) and in the variety of Spanish spoken in the Basque Country (Silva-Corvalán 1982).

\section{Method}

The study is based on a task that requires participants to discuss alternative scenarios based on a story describing a chain of related events. We henceforth refer to this task as the 'mutation task'. Note that previous studies dealing with conditional constructions have elicited their data from spontaneous speech (Bowerman 1986; Chini 1995; Katis 1997; Schouten 2000), what if- questions (Bates 1976; Reilly 1982; Harris et al. 1996) or written questionnaires (Bloom 1981; Au 1983; Liu 1985; Schouten 2000). The mutation task has been previously used by psychological studies as a way to obtain critical judgements related to causality (Wells and Gavanski 1989; Mandel and Lehman 1996). The data we discuss come from two groups of adults: thirty French native speakers and thirty Spanish native speakers; thirty-five women and twenty- five men, the majority of them recruited at the Aix-Marseille University (cf. Appendix). Guided interviews were recorded and stored as WAV files, then transcribed using the CLAN editor for CHILDES. Data collection was done mainly in the Aix-Marseille area but also in Nijmegen (the Netherlands). The stimulus was the following 200-word text, which participants had to read.

Karen was an assistant editor for a small publishing firm. She had a rare hereditary disease called Karpinson's hemotrysoma, characterized by the lack of an enzyme that normally breaks down certain proteins in the digestive system. Because of this, fermented drinks such as wine and liqueurs can cause a severe allergic reaction in someone with the disease. 
Karen had just received a promotion so her boss, Mr Carlson, took her to an expensive French restaurant to celebrate. Mr Carlson had been to this restaurant several times, so he ordered for both of them. As he looked over the menu, Mr Carlson considered what to order for Karen. He first thought about ordering the Coquilles Saint-Jacques, but at the last moment decided on the Moules Mariniere instead. Although Mr Carlson did not know this, the Moules Mariniere was made in a wine sauce whereas the Coquilles Saint- Jacques did not contain any wine.

Karen enjoyed her meal greatly, but began to feel ill shortly after finishing. Within minutes, she went into convulsions and was rushed away in an ambulance. She died on the way to the hospital.

The original text was in English (Wells and Gavanski 1986). For the experiment, it was translated in French and Spanish and then edited by two native reviewers in each language (cf. Appendix). After reading the text, the participants were asked to comply with the following instruction:

Imagine three modifications that could have been different in the story to avoid Karen's death.

We assume that every text answers an implicit question (Klein and Stutterheim 2006).5 The identification of the mutation cores, i.e. the segments of the information responsible for a modification, was possible after a qualitative analysis that allowed us to distinguish foreground structures and background structures. Consider the following example:

1. *SBJ: bon déjà il aurait pu choisir les coquilles Saint-Jacques.

He could have chosen the Coquilles Saint-Jacques.

2. *SBJ: au lieu de choisir les moules marinières. Instead of the Moules Mariniere.

\section{3. *SBJ: puisque dans les coquilles Saint-Jacques il n'y avait pas d'alcool.} Since the Coquilles Saint-Jacques contained no alcohol.

4. *SBJ: alors qu'y en avait dans les moules marinières. Whereas the Moules did.

5. *SBJ: elle aurait pu choisir toute seule son plat.

She could have chosen her own dish.

6. *SBJ: au lieu de laisser choisir par lui. Instead of allowing him to choose it.

\section{7. *SBJ: ou je [ne] sais pas.}

Or I don't know.

8. *SBJ: elle aurait pu ne pas être allergique aussi.

She could have not been allergic for instance. 
9. *SBJ: et du coup elle aurait pu les manger.

203 And thus, she could have eaten the Moules.

204 10. *SBJ: sans être malade et sans mourir.

205 Without getting sick and without dying.

206 In the example above, lines 1, 5 and 8 correspond to the text's foreground structure containing the core 207 information that really answers the quaestio, whereas lines 3, 4, 9 and 10 can be consider ed background 208 structures. The mutation cores were classified according to their formal composition in an Excel file. 209 Statistical analyses were run using the software R.

\section{Results}

211 Among the different elements encoding counterfactuality we can distinguish (i) syntactic elements, e.g. 212 conditional constructions, (ii) lexical elements, e.g. modal verbs, and (iii) inflectional elements denoting 213 a particular verbal tense and mood.6 We elicited ninety responses per group (three responses per 214 participant). The alternative scenarios to factual past events were encoded by mutation cores produced 215 within four types of clauses in French and Spanish:

216 A. Conditional constructions. Example:

217 (9) Si Karen n'avait pas eu de promotion, elle (ne) serait pas morte.

218 If Karen had not got the promotion, she would not have died.

219 (10) Si no la hubieran ascendido, no la habrían invitado a cenar.

220 If she had not been promoted, she wouldn't have been invited to dinner.

221 B. Clauses combining a conditional tense and a modal marker. Example:

222 (11) Elle aurait pu choisir toute seule son plat.

223 She could have chosen her own dish.

224 (12) Carlson podría haber pedido las vieiras.

225 Carlson could have ordered the scallops.

226 C. Coordinate clauses in verbal forms of the indicative mood, either the present tense (13) or past tenses 227 (14). This type of structure recalls that of a chronological narration because of the recurrent use of the 228 additive conjunctions et in French and $y$ in Spanish (and). Example:

229 (13) Karen est invitée par son patron donc au restaurant mais elle l'avertit qu'elle a une allergie et elle 230 lui demande de choisir elle-même son plat.

231 Karen is invited by her boss to the restaurant but she tells him she's allergic and she asks him if she can 232 choose her dish herself. 
(14) Karen comió las vieiras, se empezó a sentir mal y en el propio restaurante había un médico [...] y entonces finalmente sí salvó su vida.

Karen ate the scallops, she felt ill but a doctor was in the restaurant [...] and eventually she survived.

D. Simple clauses introduced by que - in verbal forms of the subjunctive. Example:

(15) Qu'il commande autre chose que les moules.

Let him order something other than the Moules.

(16) Que ella hubiera informado en su trabajo que sufría esa enfermedad.

She might have informed people at her job that she had that disease.

Table 2 summarizes the frequency in the use of the four constructions listed above in French. Statistical analyses using the chi-squared test revealed a significant difference between the frequency in the use of Type $B$ and Type $C(p$-value $=0.0004)$. This suggests an overt preference to produce mutation cores combining a conditional tense with a modal marker over coordinate clauses in verbal forms of the indicative. No significant differences were found between Type B, i.e. the combination of a conditional tense and a modal marker, and Type $A$ and Type $D$, i.e. conditional constructions and simple clauses in the subjunctive, respectively. The lack of significant differences suggests that these three grammatical devices play a prominent role in the expression of counterfactuality in French.

Table 2. Mutation cores in French $(n=90)$

\begin{tabular}{|c|c|c|c|}
\hline Type A & Type B & Type C & Type D \\
\hline 19 & 32 & 11 & 19 \\
\hline
\end{tabular}

Table 3 summarizes the frequency in the use of the four constructions in Spanish. The frequency in the use of Type $D$ was found to be significant compared to any of the other three constructions. In other words, simple clauses introduced by que in a subjunctive verbal form are the preferred way to conceptualize counterfactual scenarios in Spanish. The use of conditional constructions (Type A) in the mutation task in Spanish was significantly lower compared to clauses in the subjunctive mood ( $p$-value = 8.566e-15).

Table 3. Mutation cores in Spanish $(n=90)$

\begin{tabular}{|c|c|c|c|}
\hline Type A & Type B & Type C & Type D \\
\hline 6 & 3 & 7 & 58 \\
\hline
\end{tabular}


Table 4 compares the ways in which the mutation cores are encoded in French and Spanish. We established a decision threshold of 0.001 to minimize Type I errors.7 The results of the comparison of French and Spanish underlines two salient differences concerning the distribution of the grammatical devices encoding counterfactuality. Spanish speakers preferred the subjunctive mood introduced by que, whereas French speakers favoured the combination of a modal marker and the conditional tense.

Table 4. Conditional constructions v. other verbal predicates $(n=90)$

\begin{tabular}{|l|c|c|c|c|}
\cline { 2 - 5 } \multicolumn{1}{c|}{} & Type A & Type B & Type C & Type D \\
\hline French & 19 & 32 & 11 & 19 \\
\hline Spanish & 6 & 3 & 7 & 58 \\
& 0.009 & $1.34 \mathrm{e}-04^{*}$ & 0.456 & $1.036 \mathrm{e}-08^{*}$ \\
\hline
\end{tabular}

\section{Discussion}

Conditional constructions are not the most common way of referring to counterfactual worlds, neither for the French native speakers nor for the Spanish native speakers. The attention paid to conditional constructions in previous studies devoted to hypotheticality and counterfactuality has been explained because of its iconicity within the cognitive process of thinking about alternative situations (Ferguson et al. 1986). Our study provides empirical evidence that conditionality is one possible way among others in which one can refer to counterfactual worlds. However, counterfactuality is frequently expressed using grammatical devices other than conditional constructions. In French, evidence has been given about the prominent role of clauses combining the conditional tense and a modal marker (Type B), simple clauses in the subjunctive mood (Type D) and conditional constructions (Type A). In Spanish, we have shown that conditional constructions are rare compared to clauses in the subjunctive introduced by que.

Our results support the conclusion by Hellberg (1971) about the predominance of simple sentences with a conditional tense as the most frequent device to express hypotheticality in French. Our study suggests that the role assigned to conditional constructions as a prominent category to express hypotheticality and counterfactuality (Grevisse 1986; Renzi and Salvi 1991; Campos 1993; Alarcos-Llorach 1999; Traugott et al. 1986; Athanasiadou and Dirven 1997) is not empirically based on the observation of natural languages. Previous studies have portrayed conditionality as a way 'to reason about situations, to make inferences based on incomplete information, to imagine possible correlations between situations and to understand how the world would change if certain correlations were different' (Ferguson et al. 1986: 19). The interest paid to conditionality as a resource for conceptualizing irrealis or imagined scenarios has neglected the description of other ways to express these semantic domains and thus has provided an incomplete description of the conceptualization of counterfactuality. The nonprominent role of the conditional constructions to speak about what might have been but was not in 
Spanish and French suggests that the status of conditionality as a conceptualization process needs to be reconsidered. This idea finds support in the balanced distribution of the conditional constructions, the subjunctive mood and the combination of the conditional tense and modal markers across the mutation cores in French. Each group's preferences in respect to marking counterfactuality have implications in terms of typological distance. The compositional semantics of counterfactuality, i.e. the features of virtuality and non-actualization, was satisfied by the use of the subjunctive in Spanish and by the combination of a past marker and a modal marker in French. The presence of a modal marker in the mutation core was the most salient difference when comparing these Romance languages. The frequent use of evaluative particles in the mutation cores in French was implemented by means of the modal verbs pouvoir and devoir, i.e. pu and dû (could and should in English), in the past participle form within the past conditional structure. This is coherent with the description of the most frequent counterfactual marker in natural languages, which is not one single dedicated marker but rather the combination of a past tense and a modal marker (Van Linden and Verstraete 2008). Modalizers are well known for their wide range of forms, meanings and uses, and by the absence of univocal relationships between these three dimensions (Roulet 1993). However, this is not the case for the modal markers elicited in the French mutation cores. As we explained supra, the French modal verbs pouvoir and devoir were systematically used in the past participle form in a perfect conditional framework. For instance, no pu / dû were found in the passé compose (e.g., Elle a pu choisir toute seule son plat). To us, this fact reveals the univocal relationship between the 'modalized conditional' and its use for altering a factual past scenario in French. A further question concerns the type of modality expressed by this form. When saying Elle aurait pu choisir toute seule son plat ('She could have chosen her own dish'), the speaker is not expressing any epistemic or deontic modal value, since she is not attaching beliefs or nuances of obligation. We posit that the modal values expressed when using the modalized conditional for mutation purposes are evaluative. By saying Elle aurait pu choisir toute seule son plat ('She could have chosen her own dish'), the speaker attaches the pertinence of a specific action within a set of particular conditions. This coincides with the notion of evaluative modality (Palmer 1986: 119), which expresses the speaker's attitude over known factual events. This is why the expression of regret is often linked to evaluative modals (Palmer 1986: 115). The frequency in the use of this 'modalized conditional' in the mutation task is coherent with the French pattern of retelling a linear story from a narrator's point of view by the use of predicates relating to intentions, attitudes and perceptions (Carroll et al. 2008). These authors have shown that the predicates of French speakers generally refer to the mental states of the protagonist in the story, e.g. il est perplexe, il s' apercoit, il s'est dit que... (he's perplexed, he realizes, he told himself that...). The use of the 'modalized conditional' in counterfactual contexts sounds concordant with the subjective pattern in narrative tasks. There are various reasons that might explain the frequent use of the modalized conditional by native speakers of French. First, the modalized conditional results from the combination of two processes: the grammatical activation of a specific past tense, i.e. the past conditional, and the lexical activation of a modal verb in the past participle form. When these two processes converge, the listener may have access to the speaker's subjectivity in a more direct way than through other structural devices such as conditional sentences or even the indicative mood, which generally do not accommodate modal values in the mutation core. These pragmatic implications may be the first factor in explaining the high frequency of this structure in French. The second explanation 
concerns the economy factor. Unlike conditional constructions, the modalized conditional is generally not subordinated to a main clause. Moreover, in just three syllables (aurait pu / dû) the speaker is opening the door to another possible world by using the same verb tense as they might have used in a main conditional clause while avoiding the production of an antecedent $(\mathrm{P})$. It could be argued that the prominent role of the 'modalized conditional' in French may be explained by the fact that the task instruction itself contains the 'modalized conditional'. If that was the case and the input structures of the mutation task played a real effect on the data elicited, then one might expect the same effect in the Spanish corpus. However, in Spanish, the 'modalized conditional' of the input is not prominently reproduced by the Spanish native speakers. Additional data elicited in Italian L1 (Repiso 2013) confirmed no correlation between the 'modalized conditional' of the input and the responses of the native speakers of Italian. The prominent use of the subjunctive in Spanish in the mutation task might be explained because of the frequency in general of this type of structure in Spanish. In fact, the subjunctive in Spanish is semantically associated with the irrealis domain (Real Academia Española 2009: 1866). Among the uses of the irrealis subjunctive, we find the expression of threat related to the future, e.g. Que se quejen ('Let them complain') or Que vengan mañana ('We'll see if they come tomorrow'). We maintain that, unlike the examples mentioned, the occurrences elicited in the mutation task, e.g. Que ella hubiera informado en su trabajo que sufría esa enfermedad ('She might have informed people at her job that she had that disease'), are semantically anchored to the unreal past frame (Harris 1986). In Spanish, different grammatical devices may allow a counterfactual reading: the past perfect subjunctive presented here, but also the combination of the Spanish imperfect indicative and the modal markers poder 'could' or tener que 'have to' (17) or the combination of the simple past tense and the modal deber 'should' (18). For example:

(17) Ella tenía que haber informado que sufría esa enfermedad. She should have informed that she had that disease.

(18) El señor Carlson debió preguntar qué prefería comer ella. MrCarlson should have asked what she preferred to eat.

We interpret the use of the modal markers in (17) and (18) as evaluatives, since the speakers use them to express a critical judgement within a set of particular conditions (i.e. those established in the stimulus). Even if the counterfactual meaning may well be encoded by the Spanish imperfect indicative, our data showed that the subjunctive mood is significantly more frequently used by Spanish native speakers. In Spanish L1, we elicited 5 responses over 90 (5.5\%) combining an indicative tense plus a modal marker as in examples (17) and (18). Four responses followed the pattern of example (18) and only one response followed the pattern of example (17). The possibility of a link between certain varieties of Spanish and the use of the simple past tense and a modal marker to encode counterfactuality cannot be ruled out, but has not been statistically tested. However, it is interesting to note that three out of the four responses coherent with example (18) were produced by Colombian native speakers. Further studies devoted to the expression of counterfactuality are still necessary to explore possible differences across the American and peninsular varieties of Spanish. 


\section{Conclusion}

370 Our objective has been to examine the grammatical devices encoding counterfactuality in French and Spanish. Previous studies dealing with the expression of counterfactuality have approached this category by analysing conditional constructions (Bates 1976; Bloom 1981; Reilly 1982; Au 1983; Bowerman 1986; Bernini 1994; Chini 1995; Katis 1997; Schouten 2000; Yeh and Gentner 2005). Our main contribution to these studies has been to show that the mutation cores encoding counterfactual scenarios were rarely marked by bare conditional sentences in Spanish. In French, the most frequent device was the combination of the past conditional and a modal verb (e.g. Il aurait pu choisir une autre assiette, 'He could have chosen another dish'). Significant differences were found between this 'modalized conditional' and coordinate clauses in symmetrical verbal forms, suggesting that either present or past linear narrations are rare when conceptualizing what might have been but was not. In Spanish, simple clauses in the subjunctive mood were found to demonstrate significant differences compared to any of the other mutation cores, including conditional constructions. The non-prominent role of the conditional constructions suggests that the role of conditionality as a conceptualization process within irreality needs to be reconsidered. The major difference when comparing the two languages lay in the presence of a modal marker within the mutation core, significantly higher in French. The use of evaluative modals in the mutation task confirms that French tend to integrate subjective values in narrative texts, in argumentative contexts.

\section{Acknowledgements}

We are grateful to the anonymous reviewers, whose questions contributed to improving our article, and to Professor Yann Kerdilès for assisting us in the final edition of this article.

$390 \quad$ Notes

391 1. The existence of counterfactuals related to the future is controversial. Some authors claim that 392 counterfactuality cannot be related to the future, since the future has not been realized nor is known at 393 the time of utterance and thus cannot be considered against any factual state of affairs (Iatridou 2000).

394 2. Historically, the subjunctive mood in the protasis comes from Latin but it has been used less and less 395 in French since the thirteenth century (Brunot and Bruneau 1949). Th e canonical system - composed of 396 the pluperfect indicative in the protasis and the conditional perfect in the apodosis - appeared in the 397 sixteenth century.

398 3. The spoken Ottawa-Hull variety of French resolves this ambiguity by using the conditional form in the 399 protasis as a mark of potentiality and the pluperfect indicative as a mark of counterfactuality (LeBlanc 400 2009).

401 4. Example: J'aurais un peu d'argent, je m'achèteraisl' intégrale de Mozart ('Had I a little money, I would 402 buy the complete works of Mozart', Riegel et al. 1994: 558). 
5. A text is generally composed of main structures, i.e. the skeletal structure of discourse, and substructures, i.e. supportive material which does not answer the Quaestio.

6. For the sake of clarity, nominal clauses, i.e. clauses containing a nominal predicate, have been omitted from our analysis.

7. In statistics Type I errors consist in rejecting the null hypothesis when it is in fact true. The lower the threshold, the smaller is the probability to be wrongly rejecting the null hypothesis. Choosing a threshold where $\alpha=0.001$ implies less than one-in-a-thousand chance to be wrong.

\section{Works cited}

Alarcos-Llorach, E. (1999) Gramática de la lengua española (Madrid: Espasa Calpe).

Asociación de Academias de la Lengua Española \& Real Academia Española (2009) Nueva gramática de la lengua española. Sintaxis II. (Madrid: Espasa).

Athanasiadou, A. and R. Dirven (1997) 'Conditionality, hypotheticality, counterfactuality', in On Conditionals Again, ed. A. Athanasiadou and R. Dirven (Amsterdam: J. Benjamins), 61-96.

Au, T.K. (1983) 'Chinese and English counterfactuals: the Sapir-Whorf hypothesis revisited', Cognition 15, $155-87$.

Bates, E. (1976) Language and Context: The Acquisition of Pragmatics (New York: New York Academic Press).

Bernini, G. (1994) 'Le frasi ipotetiche nell'italiano di stranieri', in Italiano lingua seconda/ lingua straniera. Atti del XXVI Congresso. Società di linguistica italiana 34, ed. A. Giacalone Ramat and M. Vedovelli (Rome: Bulzoni), 271-96.

Bloom, A.H. (1981) Th e Linguistic Shaping of Th ought: A Study in the Impact of Language on Th inking in China and the West (Hillsdale, NJ: Erlbaum).

Bowerman, M. (1986) 'First steps in acquiring conditionals', in On Conditionals, ed. E. Traugott, A. ter Meulen, J. Snitzer Reilly and C. Ferguson (Cambridge: Cambridge University Press), 285-307.

Brunot, F. and C. Bruneau (1949) Précis de grammaire historique de la langue française (Paris: Masson \& (ie).

Campos, H. (1993) De la oración simple a la oración compuesta: curso superior de gramática española (Washington: Georgetown University Press).

Carroll, M., A. Rossdeutscher, M. Lambert and C. Von Stutterheim (2008) 'Subordination in narratives and macrostructural planning: a comparative point of view', in 'Subordination' versus 'Coordination' in Sentence and Text, ed. C. Fabricius-Hansen and W. Ramm (Amsterdam: S. Benjamins), 161-84. 
434

435

436

437

438

439

440

441

442

443

444

445

446

447

448

449

450

451

452

453

454

455

456

457

458

459

460

461

462

463

464 465

Chini, M. (1995) 'Meno male che non elo un topo, se no mi mangia un gatto, pe fi nta. Precursori e genesi dei costruitti ipotetici in una bambina italofona', in From Pragmatics to Syntax. Modality in Second Language Acquisition, ed. Giacalone Ramat and Crocco Galèas (Tübingen: Narr), 143-72.

Comrie, B. (1986) 'Conditionals: a typology', in On conditionals, ed. E. Traugott, A. ter Meulen, J. Snitzer Reilly and C. Ferguson (Cambridge: Cambridge University Press), 77-99.

Dancygier, B. and E. Sweetser (1996) 'Conditionals, distancing, and alternative spaces', in Conceptual Structure, Discourse and Language, ed. Adele E. Goldberg (San Diego: Stanford University), 83-98.

Fauconnier, G. (1984) Espaces mentaux. Aspects de la construction du sens dans les langues naturelles (Paris: Minuit).

Ferguson, C.A., J.S. Reilly, A. t. Meulen and E.C. Traugott (1986) 'Overview', in On Conditionals, ed. E.C. Traugott, A. t. Meulen, J.S. Reilly and C.A. Ferguson (Cambridge: Cambridge University Press), 3-20.

Grevisse, M. (1986) Le bon usage (Paris-Gembloux: Duculot). Grevisse, M. and A. Goosse (2008) Le bon usage. Grammaire française, 13th edn (Brussels: De Boeck-Duculot).

Harris, M.B. (1986) 'Th e historical development of si- clauses in romance', in On Conditionals, ed. E. Traugott, A. ter Meulen, J. Snitzer Reilly and C. Ferguson (Cambridge: Cambridge University Press), 26584.

Harris, P.L., T. German and P. Mills (1996) 'Children's use of counterfactual thinking in causal reasoning', Cognition 61(3), 233-59. Hellberg, G. (1971) Le Système hypothétique dans le français écrit et parlé. PhD thesis. University of Stockholm. Hume, D. (1739/1992) Treatise of Human Nature (New York: Prometheus).

Iatridou, S. (2000) 'Th e grammatical ingredients of counterfactuality', Linguistic Inquiry 31, 231-70.

Kahneman, D. and A. Tversky (1982) 'The simulation heuristic', in Judgment under Uncertainty: Heuristics and Biases, ed. D. Kahneman, P. Slovic and A. Tversky (New York: Cambridge University Press), 201-8.

Katis, D. (1997) 'Th e emergence of conditionals in child language: are they really so late?', in On Conditionals Again, ed. A, Angeliki and R. Dirven (Amsterdam: Benjamins), 355-85.

Klein, W. and C. von Stutterheim (2006) 'How to solve a complex verbal task: text structure, referential movement and the quaestio', Aquisicao de Línguas Estrangeiras 30(31), 29-67.

Lavandera, B. (1976) 'Linguistic structure in sociolinguistic analysis', Working Papers in Sociolinguistics 31, 2-13.

LeBlanc, C. (2009) 'Conditional morphology in si- clauses: a Canadian-French reanalysis', Canadian Journal of Linguistics 54(2), 317-37, 1001-1021. 
Lewis, D. (1973/1993) 'Causation', in Causation, ed. E. Sosa and M. Tooley (Oxford: Oxford University Press), 193-204.

Liu, L.G. (1985) 'Reasoning counterfactually in Chinese: are there any obstacles?', Cognition 21(3), 23970. Lyons, J. (1977) Semantics (Glasgow: Collins).

Mackie, J.L. (1980) 'Causes and conditions', American Philosophical Quarterly 24, 245-64. Reprinted in Causation (Oxford: Oxford University Press).

Mandel, D. and D. Lehman (1996) 'Counterfactual thinking and ascriptions of cause and preventability', Journal of Personality and Social Psychology 71(3), 450-63.

Palmer, F.R. (1986) Mood and Modality (Cambridge: Cambridge University Press). Patard, A. (2007) L'un et le multiple. L'imparfait de l'indicatif en francais: valeur en langue et usages en discours. PhD thesis, Université Paul-Valery, Montpellier III.

Pietrandrea, P. (2012) 'The conceptual structure of irreality. A focus on nonexclusion-of-factuality as a conceptual and linguistic category', Language Sciences 34(2), 184-99.

Reilly, J.S. (1982) The Acquisition of Conditionals in English. PhD dissertation. Los Angeles, University of California.

Renzi, L. and G. Salvi (1991) Grande grammatica italiana di consultazione, Vol. II (Bologna: II Mulino).

Repiso, I. (2013) Parlons de l'irréel. L'expression de la contrefactualité en français, en espagnol et en italien et par des apprenants hispanophones et italophones de français. PhD thesis. Aix-Marseille University.

Riegel, M., J.-C. Pellat and R. Rioul (1994) Grammaire méthodique du français (Paris: Presses Universitaires de France). Roulet, E. (1993) 'Des formes et des emplois des modalisateurs de proposition dans I'interaction verbale', in Modalité et acquisition des langues, ed. N. Dittmar and A. Reich (Berlin: de Gruyter), 27-40.

Schouten, E. (2000) The Role of the Native Language in the Non-Native Acquisition of Hypothetical Conditional Structures. PhD dissertation. University of Nijmegen.

Silva-Corvalán, C. (1982) 'Conditional for subjunctive in Old Castile', Proceedings of the Eight Annual Meeting of the Berkeley Linguistics Society, 87-96.

Traugott, E.C., A.G. t. Meulen, J.S. Reilly and C.A. Ferguson (eds) (1986) On Conditionals (Cambridge: Cambridge University Press).

Van Linden, A. and J.-C. Verstraete (2008) 'Th e nature and origins of counterfactuality in simple clauses: cross-linguistic evidence', Journal of Pragmatics 40, 1865-95. 
Verstraete, J.-C. (2005) 'The semantics and pragmatics of composite mood marking: the non-PamaNyungan languages of northern Australia', Linguistic Typology 9(2), 223-68.

Vetters, C. (1994) 'À propos de l'imparfait après "si"', in L'Emprise du sens. Structures linguistiques et interpretations, ed. M. Plénat, M. Aurnague, A. Condamines, J.-P. Maurel, Ch. Molinier and Cl. Muller (Amsterdam: Rodopi), 337-52.

Wald, B. (1993) 'On the evolution of "would" and other modals in the English spoken in East Los Angeles', in Modality in Language Acquisition, ed. N. Dittmar and A. Reich (Berlin: de Gruyter), 59-96.

Wells, G.L. and I. Gavanski (1989) 'Mental simulation of causality', Journal of Personality and Social Psychology 56(2), 161-69.

Yeh, D. and D. Gentner (2005) 'Reasoning counterfactually in Chinese: picking up the pieces', Proceedings of the Twenty-seventh Annual Meeting of the Cognitive Science Society, 2410-15.

Isabel Repiso was born in Valladolid, Spain in 1981. She graduated in Translation Studies from the University of Salamanca in 2003 and moved to Paris to complete a Master of Advanced Studies in Applied Linguistics under the supervision of Daniel Véronique (Université III - Sorbonne Nouvelle). Back in Madrid, she switched to Communication and Journalism (Universidad Complutense de Madrid) and spent the last part of her training at the daily newspaper ABC. In Spain, she worked as a full-time journalist for El Heraldo de Soria and Público, among other media. In September 2010 she started a PhD in Linguistics under the supervision of her former professors, Daniel Véronique (Aix-Marseille University) and Danielle Dubroca-Galin (University of Salamanca). From 2012 to 2013 she moved temporarily to Nijmegen (The Netherlands) to accomplish her research under the supervision of Wolfgang Klein, director of the Department of Language Acquisition at the Max Planck Institute for Psycholinguistics. She received her PhD degree in December 2013 and held a six-month post-doctoral project at Nanyang Technological University (Singapore). Since September 2014, she has taught at the University of Upper Alsace in the framework of an MA in Translation Studies. In November 2014, her PhD dissertation was outlined in the Aix-Marseille University's top fifteen and was awarded by the School of Cognition, Language \& Education with the 'Prix de Thèse 2013'.

\section{APPENDIX}

Stimulus and instructions: Mutation task

Karen était assistante à l'édition dans une petite agence de publicité. Elle avait une rare maladie héréditaire, l'hémotrisoma de Karpinson, caractérisée par le manque d'une enzyme qui normalement divise certaines protéines du système digestif. En raison de cela les boissons fermentées comme le vin ou les liqueurs pouvaient lui causer des sévères réactions allergiques. Karen avait eu une promotion dans son travail et son supérieur, monsieur Carlson, l'avait emmenée dans un restaurant français plutôt cher pour l'y fêter. Etant donné que monsieur Carlson avait mangé plusieurs fois dans ce restaurant il commanda pour les deux. Pendant qu'il regardait le menu il considérait quel plat commander pour 
532 Karen. Il pensa d'abord aux coquilles Saint-Jacques mais au dernier moment il choisit les moules 533 marinières. Monsieur Carlson ne le savait pas mais les moules marinières étaient cuites dans une sauce

534 à base de vin tandis que les coquilles Saint-Jacques ne contenaient pas de vin. Karen savoura son plat 535 mais elle commença à se sentir mal peu après avoir fi ni. Quelques minutes plus tard elle souffrit de 536 convulsions et elle fut transportée en ambulance. En chemin pour l'hôpital elle mourut.

537 Proposez trois modifications qui auraient pu empêcher la mort de Karen et expliquez pourquoi elles 538 auraient empêché sa mort.

Karen era asistente a la edición en una pequeña empresa de publicidad. Padecía una rara enfermedad 541 hereditaria llamada hemotrisoma de Karpinson, caracterizada por la falta de una enzima que 542 normalmente divide algunas proteínas en el aparato digestivo. Por ello las bebidas fermentadas como el 543 vino o el licor podían causarle graves reacciones alérgicas. Karen había sido ascendida de manera que su 544 superior, el señor Carlson, la llevo a un caro restaurante francés para celebrarlo. El señor Carlson había 545 comido en dicho restaurante varias veces, así que pidió por ambos. Mientras miraba el menú se 546 preguntó que pedir para Karen. Primero pensó en pedir unas vieiras pero en el último momento se 547 decidió por los mejillones a la marinera. Aunque el señor Carlson no lo sabía, los mejillones a la marinera 548 llevaban una salsa a base de vino mientras las vieiras, no. Karen disfrutó de la comida pero empezó a 549 sentirse mal poco después. En cuestión de minutos sufrió convulsiones y fue socorrida en una 550 ambulancia. Karen murió de camino al hospital.

551 Imagina tres modificaciones de la historia que habrían podido evitar la muerte de Karen y explica por 552 qué habrían evitado su muerte. 